\title{
DAYA TERIMA DAN KANDUNGAN GIZI COOKIES TEPUNG SAGU KOMBINASI TEPUNG KACANG MERAH DENGAN PENAMBAHAN SARI BUAH MERAH
}

\section{Radeny Ramdany, Mustamir Kamaruddin, Ariani Pongoh, dan Eva Adelitha Suryani}

Poltekkes Kemenkes Sorong, Papua Barat, Indonesia

Email: radeny_ramdany@yahoo.com, iyotamirkha@gmail.com, ani.pongoh@yahoo.co.id dan evaadelithasuryani@gmail.com

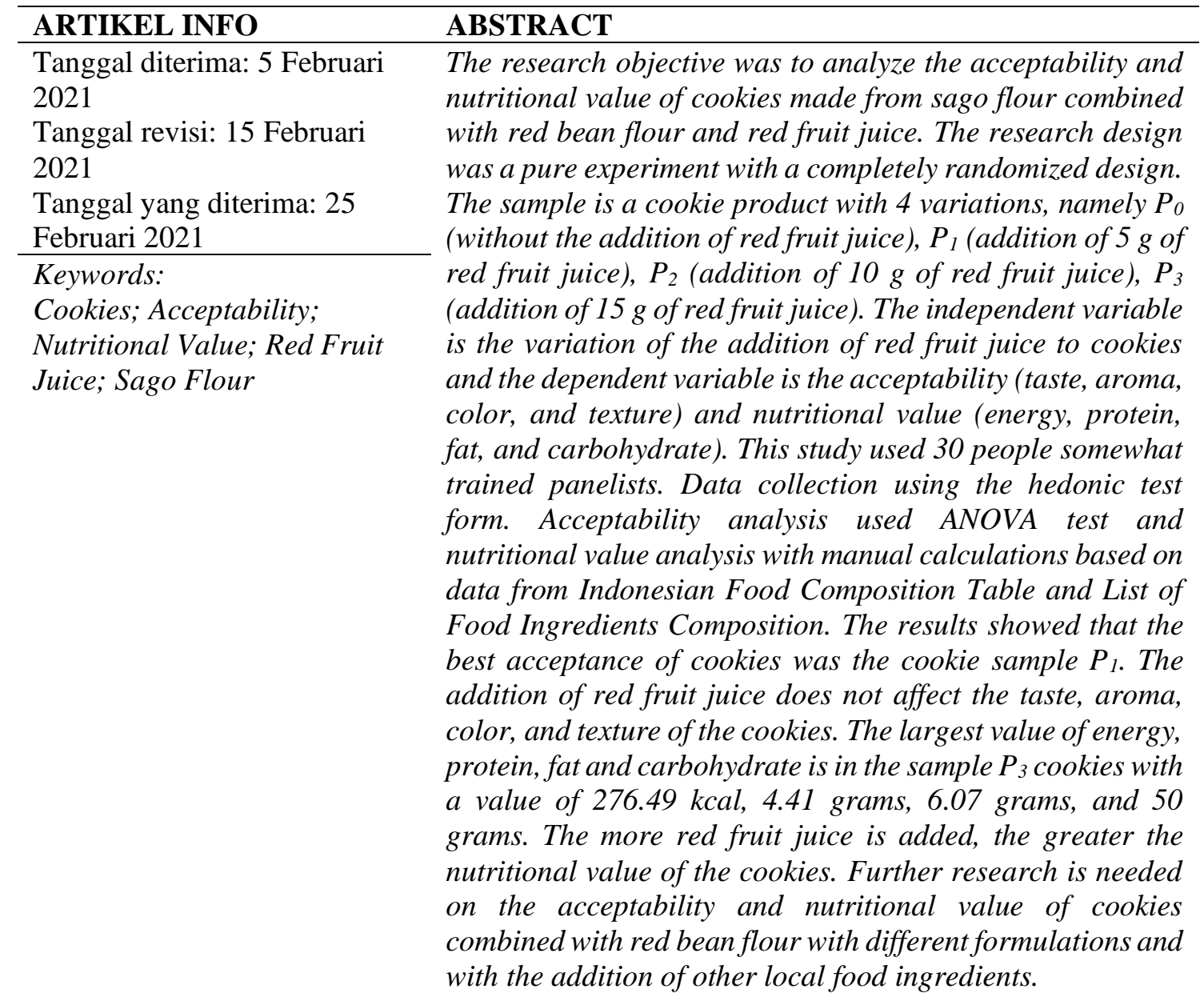

Kata Kunci:

Cookies; Daya Terima; Nilai

Gizi; Sari Buah Merah;

Tepung Sagu

\begin{abstract}
ABSTRAK
Tujuan penelitian adalah untuk menganalisis daya terima dan kandungan gizi cookies tepung sagu kombinasi tepung kacang merah dengan penambahan sari buah merah. Desain penelitian adalah eksperimen murni dengan Rancangan Acak Lengkap (RAL). Sampel adalah produk cookies dengan 4 variasi yaitu P0 (tanpa penambahan sari buah merah), P1 (penambahan sari buah merah sebanyak $5 \mathrm{~g}$ ), P2 (penambahan sari buah merah sebanyak $10 \mathrm{~g}$ ), P3 (penambahan sari buah merah sebanyak $15 \mathrm{~g}$ ). Variabel independent adalah variasi penambahan sari buah merah
\end{abstract}




\begin{tabular}{l} 
pada cookies dan variabel dependent adalah daya terima \\
(rasa, aroma, warna, dan tekstur) dan kandungan gizi (energi, \\
protein, lemak, dan karbohodrat). Penelitian ini \\
menggunakan panelis agak terlatih sebanyak 30 orang. \\
Pengumpulan data menggunakan formulir uji hedonik. \\
Analisis daya terima menggunakan uji ANOVA dan analisis \\
kandungan gizi dengan perhitungan manual berdasarkan data \\
dari TKPI (Tabel Komposisi Pangan Indonesia) dan DKBM \\
(Daftar Komposisi Bahan Makanan). Hasil penelitian \\
menunjukan bahwa daya terima cookies yang paling baik \\
adalah pada sampel cookies P1. Penambahan sari buah \\
merah tidak memberikan pengaruh terhadap rasa, aroma, \\
warna, dan tekstur dari cookies. Kandungan energi, protein, \\
lemak dan karbohidarat terbesar adalah pada cookies sampel \\
P_3 dengan nilai 276.49 kkal, 4.41 gram, 6.07 gram, dan 50 \\
gram. Semakin banyak penambahan sari buah merah maka \\
semakin besar kandungan gizi dari cookies. Perlu adanya \\
penelitian lanjutan tentang daya terima dan nilai gizi cookies \\
tepung sagu kombinasi tepung kacang merah dengan \\
formulasi yang berbeda dan dengan penambahan bahan \\
pangan lokal yang lainnya. \\
\hline
\end{tabular}

Coresponden Author:

Email: radeny_ramdany@yahoo.com Artikel dengan akses terbuka dibawah lisensi

\section{Pendahuluan}

Cookies merupakan salah satu produk bakery yang populer di semua kalangan, terbuat dari tepung terigu namun tidak memerlukan pengembangan (unleavened product), melalui proses pencetakan dan pemanggangan serta diutamakan kerenyahan teksturnya dengan kadar air yang harus kurang dari 5\% (Yasinta et al., 2017).

Cookies pada umumnya terbuat dari tepung terigu yang merupakan komoditas import Indonesia. Oleh karena itu, untuk mengurangi ketergantungan terhadap penggunaan tepung terigu maka bahan pangan tersebut dapat disubtitusi dengan bahan pangan alternatif lainnya yang berasal dari pangan lokal seperti tepung sagu (Turisyawati, 2011).

Tanaman sagu banyak tumbuh di berbagai wilayah di Indonesia, seperti Papua,
Papua Barat, Sulawesi, Maluku, Riau dan Kalimantan. Oleh karena itu, tanaman sagu sangat potensial untuk dikembangkan sebagai bahan pangan alternatif. Di Indonesia, penggunaan tepung sagu sebagai bahan pangan telah banyak dikenal dalam berbagai bentuk produk, diantaranya papeda, sagu lempeng, sagu tutupala, sagu uha, sinoli, bagea, dan lainnya (Kusuma et al., 2013).

Subtitusi tepung sagu dalam pembuatan cookies berguna sebagai salah satu sumber karbohidrat, sedangkan untuk menambahkan sumber protein dapat dikombinasikan dengan tepung kacang merah (Budijanto, 2009). Teknologi penepungan menggunakan kacang merah telah banyak dilakukan dalam berbagai penelitian yang membuat tepung kacang merah sebagai bahan olahan produk kue dan cake.

Jurnal Health Sains Vol. 2, No. 2, Februari 2021 
Selain dua bahan utama tersebut, untuk lebih meningkatkan nilai gizi dari cookies maka dapat ditambahkan pula bahan lokal lainnya seperti sari buah merah.

Buah merah (Pandanus conoideus) merupakan jenis tanaman yang termasuk ke dalam famili pandanaceae dan ditemukan secara endemik di Provinsi Papua dan Papua Barat. Pemanfaatan buah merah yang dikonsumsi oleh masyarakat lokal adalah dengan cara infusa, kemudian sari buah merah yang telah terbentuk dapat langsung dikonsumsi ataupun diolah lagi. Didalam pengolahannya, sari buah merah biasa dicampur pada ubi yang menjadi makanan pokok yang dikonsumsi bersama dengan lauk. Selain dicampur, sari buah merah juga biasa dikonsumsi langsung dalam bentuk minuman (Ayomi, 2015).

Buah merah mengandung tinggi kalori, kalsium, serat, protein, vitamin B1, vitamin C. Kandungan kalorinya mencapai 400 kilo kalori/100 gram daging buah. Kandungan antioksidan terutama $\beta$ karoten dan $\alpha$ tokoferol dalam buah merah lebih tinggi dibandingkan buah dan sayuran lainnya, seperti tomat, wortel, pepaya,maupun taoge (Ayomi, 2015).

Tujuan dilakukannya penelitian ini adalah untuk menganalisis daya terima dan kandungan gizi dari cookies tepung sagu kombinasi tepung kacang merah dengan penambahan sari buah merah. Pemanfaatan tepung sagu, tepung kacang merah dan sari buah merah dalam pembuatan cookies diharapkan dapat meningkatkan kandungan gizi cookies dan mengangkat potensi pangan lokal.

\section{Metode Penelitian}

Penelitian dilaksanakan di Laboratorium Teknologi Pangan, Jurusan Gizi Poltekkes Kemenkes Sorong pada bulan MeiJuli 2020. Desain penelitian yang digunakan adalah eksperimen murni dengan Rancangan Acak Lengkap (RAL). Variabel independent adalah variasi penambahan sari buah merah pada cookies dan variabel dependent adalah daya terima (rasa, aroma, warna, dan tekstur) dan kandungan gizi (energi, protein, lemak, dan karbohodrat).

Sampel yang digunakan sebagai obyek penelitian adalah cookies tepung sagu kombinasi tepung kacang merah dengan penambahan sari buah merah, dengan 4 variasi sampel yaitu $\mathrm{P}_{0}, \mathrm{P}_{1}, \mathrm{P}_{2}$, dan $\mathrm{P}_{3}$ seperti pada Tabel 1.

\section{Tabel 1}

Komposisi Bahan Pembuatan Cookies Tepung Sagu Kombinasi Tepung Kacang Merah dengan Penambahan Sari Buah Merah

\begin{tabular}{ccccc}
\hline \multirow{2}{*}{ Bahan (g) } & \multicolumn{4}{c}{ Sampel } \\
\cline { 2 - 5 } & $\boldsymbol{P}_{\mathbf{0}}$ & $\boldsymbol{P}_{\mathbf{1}}$ & $\boldsymbol{P}_{\mathbf{2}}$ & $\boldsymbol{P}_{\mathbf{3}}$ \\
\hline $\begin{array}{c}\text { Sari Buah } \\
\text { Merah }\end{array}$ & 0 & 5 & 10 & 15 \\
\hline Margarin & 100 & 100 & 100 & 100 \\
\hline Gula & 125 & 125 & 125 & 125 \\
\hline Telur & 50 & 50 & 50 & 50 \\
\hline $\begin{array}{c}\text { Susu Kental } \\
\text { Manis }\end{array}$ & 10 & 10 & 10 & 10 \\
\hline Susu Bubuk & 6,75 & 6,75 & 6,75 & 6,75 \\
\hline Vanili & 1.25 & 1,25 & 1,25 & 1,25 \\
\hline Tepung Sagu & 250 & 250 & 250 & 250 \\
\hline $\begin{array}{c}\text { Tepung Kacang } \\
\text { Merah }\end{array}$ & 110 & 110 & 110 & 110 \\
\hline
\end{tabular}

Instrumen penelitian menggunakan formulir uji hedonik. Penelis yang digunakan adalah panelis agak terlatih sebanyak 30 orang Pengumpulan data dilakukan dengan membagikan formulir uji hedonik kepada panelis. Pada formulir uji hedonik panelis diminta memberikan penilaian terhadap sampel dengan 5 skala yaitu sangat suka (5), suka (4), biasa (3), tidak suka (2) dan sangat tidak suka (1) (Poste, 1991). Pengolahan data menggunakan program SPSS. Analisis daya terima menggunakan Uji ANOVA (Analysis of Variance), sedangkan variabel kandungan gizi disajikan secara deskriptif, diperoleh dari hasil perhitungan manual dengan melihat 
kandungan zat gizi setiap bahan berdasarkan data yang diperoleh dari TKPI (Tabel Komposisi Pangan Indonesia) dan DKBM (Daftar Komposisi Bahan Makanan).

\section{Hasil dan Pembahasan}

\section{Tabel 2}

\section{Hasil Uji Daya Terima Cookies}

\begin{tabular}{cccccc}
\hline & \multicolumn{5}{c}{ Parameter Uji } \\
\cline { 2 - 6 } Sampel & Warna & Aroma & Tekstur & Rasa & $\begin{array}{c}\text { Over } \\
\text { All }\end{array}$ \\
\hline$P_{0}$ & 3.5 & 3.9 & 4.0 & 4.0 & 4.0 \\
\hline$P_{1}$ & 3.7 & 4.0 & 3.9 & 4.0 & 4.1 \\
\hline$P_{2}$ & 3.4 & 3.2 & 3.4 & 3.3 & 3.6 \\
\hline$P_{3}$ & 3.8 & 3.0 & 3.7 & 3.4 & 3.6 \\
\hline
\end{tabular}

Tabel 2 menunjukkan bahwa hasil uji daya terima dari parameter warna yang paling disukai adalah sampel $\mathrm{P}_{3}$ dengan skor rata-rata 3,8 , aroma yang paling disukai adalah sampel $\mathrm{P}_{1}$ dengan skor rata-rata 4,0 , tekstur yang paling disukai adalah sampel $\mathrm{P}_{0}$ dengan skor rata-rata 4,0 , rasa yang paling disukai adalah sampel $\mathrm{P}_{0}$ dan $\mathrm{P}_{1}$ dengan skor rata-rata 4,0 , dan yang paling disukai secara keseluruhan (over all) adalah sampel $\mathrm{P}_{1}$ dengan skor rata-rata 4,1 .

Tabel 3

\section{Hasil Uji Statistik}

\begin{tabular}{ccc}
\hline Parameter & P & Signifikan \\
\hline Warna & 0,361 & NS \\
\hline Aroma & 0,643 & NS \\
\hline Tekstur & 0,843 & NS \\
\hline Rasa & 1,000 & NS \\
\hline
\end{tabular}

Berdasarkan hasil uji statistik pada Tabel 3 menunjukkan bahwa parameter warna, aroma, tekstur, rasa dari cookies memiliki nilai $\mathrm{p}>0,05$, hal ini berarti bahwa perlakuan penambahan sari buah merah pada cookies tepung sagu kombinasi tepung kacang merah tidak berpengaruh terhadap warna, aroma, tekstur, dan rasa yang dihasilkan.

\section{Tabel 4}

Hasil Perhitungan Kandungan Gizi

\begin{tabular}{ccccc}
\hline \multirow{2}{*}{ Sampel } & \multicolumn{4}{c}{ Zat gizi } \\
\cline { 2 - 5 } & $\begin{array}{c}\text { Energi } \\
\text { (kkal) }\end{array}$ & $\begin{array}{c}\text { Protein } \\
\text { (gr) }\end{array}$ & $\begin{array}{c}\text { Lemak } \\
(\mathbf{g r})\end{array}$ & $\begin{array}{c}\text { KH } \\
(\mathbf{g r})\end{array}$ \\
\hline$P_{0}$ & 217,39 & 3,92 & 1,86 & 45,22 \\
\hline$P_{1}$ & 237,09 & 4,08 & 3,26 & 46,81 \\
\hline$P_{2}$ & 256,79 & 4,25 & 4,67 & 48,41 \\
\hline$P_{3}$ & 276,49 & 4,41 & 6,07 & 50 \\
\hline
\end{tabular}

Tabel 4 menunjukkan pada sampel $\mathrm{P}_{3}$ mempunyai kandungan gizi paling baik yaitu energi 276,49 kkal, protein 4,41 gram, lemak 6,07 gram serta karbohidrat 50 gram, sedangkan pada sampel $\mathrm{P}_{0}$ (tanpa penambahan sari buah merah) mempunyai kandungan gizi paling rendah yaitu energi yaitu 217,39 kkal, protein 3,92 gram, lemak 1,86 gram, serta karbohidrat 45,22 gram.

Agar makanan yang disajikan tetap terjaga kualitasnya maka harus dievaluasi, salah satu caranya adalah dengan menghitung daya terima makanan oleh konsumen (Wijaya et al., 2017). Daya terima makanan adalah presentase makanan yang di konsumsi dari total keseluruhan yang disediakan. Daya terima ini banyak dipengaruhi beberapa faktor diantaranya adalah penampilan makanan saat disajikan dan rasa makanan (Kamaruddin et al., 2020). Untuk mengetahui hasil daya terima atau tingkat kesukaan panelis, dilakukan uji daya terima dengan menguji beberapa parameter, seperti warna, aroma, tekstur, dan rasa.

Hasil uji daya terima pada parameter warna cookies memiliki skor skala mendekati suka $(3,8)$ dengan penambahan sari buah merah adalah perlakuan $\mathrm{P}_{3}$ dan perlakuan $\mathrm{P}_{0}$, $\mathrm{P}_{1}$ dan $\mathrm{P}_{2}$ memperoleh skor skala berkisar 3,4 - 3,7 yang termasuk dalam kategori biasa mendekati suka. Faktor yang mempengaruhi warna pada cookies adalah bahan yang digunakan dalam pembuatan cookies dan adanya reaksi maillard selama proses pemanggangan. Penggunaan suhu tinggi dengan waktu yang lama dapat menyebabkan terjadinya reaksi browning non enzimatik dan karamelisasi, reaksi maillard terjadi karena adanya reaksi gugus amino protein dan gula 
(Sareani et al., 2019). Warna yang bagus dan segar sesungguhnya memiliki arti pada kondisi makanan tersebut, yang pada akhirnya menjadi daya tarik konsumen untuk memilih makanan tersebut (Kamaruddin et al., 2020).

Aroma makanan banyak menentukan kelezatan bahan makanan. Aroma lebih banyak sangkut pautnya dengan alat panca indera yaitu hidung (Suryani et al., 2016). Cookies memiliki aroma harum khas kue kering. Tingkat kesukaan panelis dengan skala 4,0 (suka) ada pada perlakuan $\mathrm{P}_{1}$ dan pada perlakuan $\mathrm{P}_{0}$ dan $\mathrm{P}_{2}$ memiliki nilai berkisar 3,2-3,9 yang termasuk dalam kategori mendekati suka. Sedangkan pada perlakuan $\mathrm{P}_{3}$ memiliki nilai berkisar 3,0 yang termasuk dalam kategori biasa. Ini disebabkan karena sari buah merah memiliki aroma langu khas buah merah, yang dalam penelitian ini beberapa panelis tidak menyukai aroma khas buah merah sehingga pada sampel cookies yang ditambahkan sari buah merah paling banyak kurang diminati. Menurut (Ramdani \& Artayasa, 2020) penambahan sari buah merah yang berlebih dapat mempengaruhi tingkat kesukaan terhadap aroma dikarenakan buah merah memiliki aroma yang khas (langu) yang agak sulit untuk dihilangkan.

Tekstur dan konsistensi suatu bahan akan mempengaruhi cita rasa yang ditimbulkan oleh bahan tersebut perubahan tekstur bahan dapat mempengaruhi kecepatan timbulnya rangsangan sel reseptor olfaktori dan kelenjar air liur (Iskandar \& Handayani, 2016). Cookies tepung sagu kombinasi tepung kacang merah dengan penambahan sari buah merah memiliki tekstur yang sangat renyah seperti cookies pada umumnya. Berdasarkan hasil uji daya terima cookies yang disukai oleh panelis ada pada perlakuan $\mathrm{P}_{0}$ (tanpa penambahan sari buah merah), pada perlakuan $\mathrm{P}_{1}, \mathrm{P}_{2}$ dan $\mathrm{P}_{3}$ termasuk dalam kategori mendekati suka dengan skor 3,4-3,9.

Rasa makanan dapat dikenali dan dibedakan oleh kuncup-kuncup hisapan yang terletak pada papilla yaitu bagian noda merah jingga pada lidah (Iskandar \& Handayani, 2016). Cookies dalam penelitian ini memiliki rasa gurih kue kering dengan adanya rasa khas tepung sagu. Cookies menghasilkan kesukaan panelis pada skala suka $(4,0)$ pada perlakuan $\mathrm{P}_{0}$ (tanpa penambahan sari buah merah) dan pada perlakuan penambahan sari buah merah yang memiliki tingkat kesukaan $(4,0)$ adalah $\mathrm{P}_{1}$ yang memperoleh skor tertinggi. Sedangkan pada perlakuan $\mathrm{P}_{2}$ dan $\mathrm{P}_{3}$ yang memiliki skor berkisar 3,3 - 3,4 memperoleh skor yang termasuk dalam kategori mendekati suka. Hal ini membuktikan dari beberapa panelis memiliki pendapat yang berbeda, pada dasarnya kelompok yang lebih menyukai cookies pada perlakuan kontrol karena tidak menyukai rasa dan aroma dari sari buah merah, sedangkan kelompok yang menyukai cookies pada perlakuan penambahan sari buah merah yang penambahannya sebanyak $5 \mathrm{gr}$, yang berarti bahwa dalam penelitian ini penambahan tersebut tidak terlalu besar dan tidak mendominasi rasa dari tepung sagu dan tepung kacang merah itu sendiri.

Hasil uji statistik menunjukkan bahwa tidak adanya pengaruh nyata pada semua perlakuan terhadap daya terima warna, aroma, tekstur, dan rasa dari cookies. Tidak adanya pengaruh yang signifikan pada parameter warna karena sari buah merah yang diberikan pada tiap varian dalam penelitian ini tidak memiliki perbedaan yang jauh sehingga pembandingnya hanya pada kelompok kontrol.

Parameter aroma juga menunjukkan tidak ada pengaruh disebabkan karena kedua bahan penyusun utama (tepung sagu dan tepung kacang merah) secara alamiah tidak mempunyai aroma yang tajam sehingga variasi dalam campuran tidak menyebabkan perbedaan aroma yang signifikan. Menurut (Sihotang et al., 2015), aroma khas adonan ditimbulkan dari komponen pada adonan seperti pencampuran margarine dan telur, 
aroma cookies juga dipengaruhi oleh proses pemanggangan.

Tidak adanya pengaruh yang signifikan pada tekstur disebabkan karena sari buah merah yang digunakan tiap variasi sampel komposisinya tidak berbeda jauh sehingga tidak memberi pengaruh terhadap tekstur cookies yang dihasilkan. Tekstur dari biskuit yang dihasilkan dipengaruhi oleh komposisi bahan yang digunakan (Ramdani \& Artayasa, 2020).

Pada parameter rasa tidak terdapat pengaruh disebabkan karena penambahan sari buah merah setiap sampel yang sedikit yaitu 5 g hingga $15 \mathrm{~g}$ sehingga tidak mempengaruhi rasa (Fajarwati et al., 2017). Sari buah merah yang dipakai dalam bentuk cair dan mencampur dengan adonan cookies mentega, telur, gula, dan tepung sagu serta tepung kacang merah yang menjadi dominasi rasa ketika di makan.

Dari hasil kandungan gizi ke-empat sampel, cookies ini memiliki kandungan gizi yang dapat memenuhi syarat mutu cookies menurut SNI 2973-2011, jika dikonsumsi dalam 2-3 porsi. Sehingga dapat dikonsumsi oleh kalangan usia anak sekolah hingga dewasa (Megadianti et al., 2020). Cookies tepung sagu kombinasi tepung kacang merah pada penelitian ini dapat dijadikan makanan cemilan atau snack, karena masih termasuk dalam jenis biskuit dan memiliki kandungan energi dan karbohidrat yang cukup tinggi.

Sampel yang memiliki kandungan energi, protein, lemak, dan karbohidrat paling tinggi adalah pada sampel $\mathrm{P}_{3}$, hal ini dikarenakan pada sampel $\mathrm{P}_{3}$ diberikan penambahan sari buah merah paling banyak yaitu 15 gr, sedangkan sampel yang menghasilkan kandungan energi, protein, lemak, dan karbohidrat paling sedikit adalah pada sampel $\mathrm{P}_{0}$, hal ini dikarenakan pada sampel $\mathrm{P}_{0}$ tidak diberikan penambahan sari buah merah.

\section{Kesimpulan}

Daya terima cookies secara keseluruhan yang paling baik adalah sampel $\mathrm{P}_{1}$ yaitu cookies tepung sagu kombinasi tepung kacang merah dengan penambahan sari buah merah sebanyak 5 gr. Uji statistik menunjukkan bahwa variasi penambahan sari buah merah pada cookies tepung sagu kombinasi tepung kacang merah tidak berpengaruh terhadap aroma, tekstur, warna dan rasa dari cookies yang dihasilkan. Hasil analisis kandungan zat gizi menunjukkan semakin banyak penambahan sari buah merah maka semakin besar kandungan gizi yang dimiliki cookies.

\section{BIBLIOGRAFI}

Ayomi, A. F. M. (2015). Buah Merah (Pandanus Conoideus) Terhadap Penyerapan Zat Besi (Fe) Dalam Duodenum. Jurnal Agromedicine, 2(2), 90-93.

Budijanto, S. (2009). Dukungan Iptek Bahan Pangan Pada Pengembangan Tepung Lokal. Jurnal Pangan, 18(2), 55-67.

Fajarwati, N. H., Parnanto, N. H. R., \& Manuhara, G. J. (2017). Pengaruh Konsentrasi Asam Sitrat Dan Suhu Pengeringan Terhadap Karakteristik Fisik, Kimia Dan Sensoris Manisan Kering Labu Siam (Sechium Edule Sw.) Dengan Pemanfaatan Pewarna Alami Dari Ekstrak Rosela Ungu (Hibiscus Sabdariffa L.). Jurnal Teknologi Hasil Pertanian, 10(1), 50-66.

Iskandar, A., \& Handayani, M. N. (2016). Karakteristik Saus Paprika (Capsicum Annuum) Dengan Penambahan Rosella (Hibiscus Sabdariffa) Sebagai Pewarna Alami. Edufortech, 1(1).

Kamaruddin, M., Asriany, A., \& Triananinsi, N. (2020). Kajian Pengetahuan Ibu Hamil Tentang Bahaya Asap Rokok Pada Kehamilan Di Puskesmas Herlang Kabupaten Bulukumba. Medika 
Alkhairaat: Jurnal Penelitian Kedokteran Dan Kesehatan, 2(2), 75-80.

Kusuma, P. T. W. W., Indrianti, N., \& Ekafitri, R. (2013). Potensi Tanaman Sagu \{Metroxylon Sp.) Dalam Mendukung Ketahanan Pangan Di Indonesia (Potential Of Sago Plant (Metroxylon Sp.) To Support Food Security In Indonesia). Jurnal Pangan, 22(1), 61-76.

Megadianti, J. R., Purba, J. S. R., \& Agusanty, S. F. (2020). Analisis Zat Gizi Dan Daya Terima Cookies Tepung Talas Pontianak. Pontianak Nutrition Journal (Pnj), 3(1), 24-28.

Ramdani, A., \& Artayasa, I. P. (2020). Keterampilan Berpikir Kreatif Mahasiswa Dalam Pembelajaran Ipa Menggunakan Model Inkuiri Terbuka. Jurnal Pendidikan Sains Indonesia (Indonesian Journal of Science Education), 8(1), 1-9.

Sareani, A., Suranadi, L., \& Sofiyatin, R. (2019). Substitusi Tepung Kedelai (Glyine Max L.) Terhadap Sifat Organoleptik Soybeans Cookies. Jurnal Gizi Prima (Prime Nutrition Journal), 4(1), 1-7.

Sihotang, S., Dewi, R., Nawawi, M., \& Sitompul, S. M. (2015). Keragaman
Hasil, Pada Uji 3 Galur Tanaman Kedelai (Glycine Max L. Merril) Generasi F3 Hasil Persilangan Tanggamus $X$ Anjasmoro, Tanggamus $X$ Argopuro, Tanggamus $X U b$. Brawijaya University.

Suryani, N., Yasmin, F., Jumadianor, D., Borneo, S. H., \& Borneo, A. S. H. (2016). Pengaruh Proporsi Labu Kuning (Cucurbita Moschata Durch) Terhadap Mutu (Karbohidrat Dan Serat) Serta Daya Terima Kue Kering (Cookies). Jurnal Kesehatan Indonesia, 4(3).

Turisyawati, R. (2011). Pemanfaatan Tepung Suweg (Amorphopallus Campanulatus) Sebagai Subtitusi Tepung Terigu Pada Pembuatan Cookies.

Wijaya, S. A., Sitoayu, L., \& Pakpahan, T. H. (2017). Analisis Sistem Penyelenggaraan Makanan Dan Hubungan Daya Terima, Asupan Makanan Terhadap Status Gizi Lansia. Jurnal Sains Kesehatan, 24(1), $1-8$.

Yasinta, U. N. A., Dwiloka, B., \& Nurwantoro, N. (2017). Pengaruh Subtitusi Tepung Terigu Dengan Tepung Pisang Terhadap Sifat Fisikokimia Dan Organoleptik Cookies. Jurnal Aplikasi Teknologi Pangan, 6(3). 